学を習得するのに最も適するように編集者が経験を生か して編集したものだけあって，学生の演習に便利なよ に理論が理論に終る゙ことなくな分に理解されるよう多く の訪算問題を取り报つている.

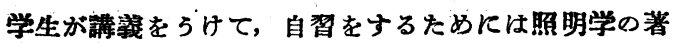
書としては「帶に短かく，たすきに長し」といわれるが 如く適当したるのが少かつたが, 本書が公にされたので ようゃくこの危機から脱した感があり，これから照明学 一を能强する学生にとつては大きい融卑といわねばならな

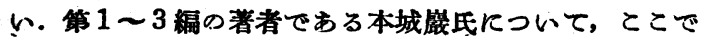
紹介するまですなく学会誌発行以來の編集委員であり,

\section{照明サロン 最近の電カ事情につルて}

例年なら 9 月から 10 月とかけては豊水期が継続され ているのに，本年は逆に電力事情は惡化の一步を近り， 逐に9月 6 日より電氣需給調整規則第 15 条による電力 制限が行われている.

これにより世界届指として夜宾を染めていたネオンゃ 凉味をそそつたナイター, ゲームも中止された。不 10 月牛ば頃からは緊急制限が行われ, 速日 2 時閒後の停電 る行われる様になり活潑化した照明界も退步を余儀なく されている．この様に電力不足を來した理由は次のこと が考え机る。

1. 30 年來の舆狀渴水

7 月 20 日から始まつた連䊀的な旱天は最もひどかつ た関西地方では实に 1 ケ月以上の日照りとなり，明治19 年の 50 日，昭和 16 年の 48 日開に匹敵する近年まれな 大渴水であつた。このよ5な記錄的な旱天によつて諸河 川○自然流量は著しく減退し，9月に入つてからは，さ らと酷く 8 月は例年より 2 割渴水，9月は 4 割渴水とい 弓恐るへき最惡狀㦔に違し，水主火從の吾国の電力事情 は䫅に惡化したのである。

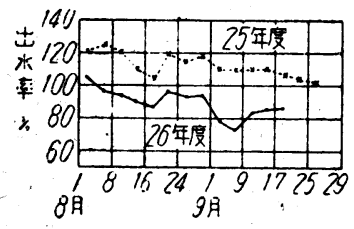

全国出水轫比較 (過去 9 ケ年平均去 100 とする)
これはひとり関西地方 のみならず広く全国的の 渴水となり，このために 電力惡化の救済策として 眝水池の水を放僦し，火 力発電所をフル運轉をす る等, 交字通り電力不足 打開に総力を挙げてい た.これに加えて例年台風シーズンと云われる 9 月に入 つてからも大雨が全然ないとい5狀態なので谷々苦境に 追い込まれていつたのである。

例元ば東京電力の猪苗代湖の水位は 9 月末に於て, 約
現在は顧問として編集のためにあらゆる御努力を拂われ 照明の発違のために御盡力をされている方である.われ われが, 照明の権威者であるばかりでなく, 常に学会の ために関心をよせられている方によつててのような良書 をるのされたことは斯界のために誠に喜びにたえない.

內容は第 1 編光源（第 1 章光，第 2 章白熱電灯，第 3 章放電灯，第 4 章澌光）第 2 編照明(第 1 章照明計算,第 2 章照明設計) 第 3 編電熱 (第 1 章電熱理論, 第 2 章電 熱施設) で 183頁がさかれてあり, 術語の取り扱いゃ姴 目のむげ方は著者の個性がよく表われている。ぜひ,一 読を扣すすめしたい。（須田）
マイナス $0.4 \mathrm{~m} ゙$ ，昨年同期のプラス $1.4 \mathrm{~m}$ に較ぺ大減 水となつている.

こころが最近”救電台風"とい われた台風ルースが本士に上陸 し電力事情にとつては旱天の慈 雨といわれ，その降雨に期待が もたれたのであるが，一部の地 力を除いて会国的な電力回復之

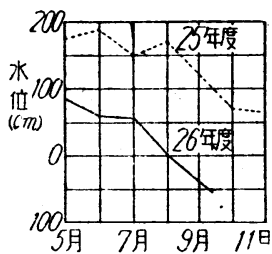

猪苗代湖水位 は言えず, ルース台風が通過した南九州, 中国, 四国の 一帶はうる括つたが, 東京, 北陵, 東北, 中部, 関西等で はやつと小康を得た程度で電力危機解消に程遠かつた.

(2) “炎力発電所の連続フル連轉

この樣な水力発電の不足を㭪うへく, 火力発電所は冬 に備える貯炭を隇らしてまで, フル運轉している. 即ち 4 月より 8 月迄の全国電力用石炭消費実績は $2,204,297$ トンであり，5月 21 日公谷委員会の発表によれば 4 〜 8 月当初計画消費 180 万トンK対し約 $22 \%$ 上趈つて 扣り, 最も電力事情の惡かつた関西需力では本年 4 月か ら 8 月迄に石炭 57 万 8 千トンを消費し計画に較へて1.4 倍の 17 万トンも余分に焚き, 昨年の 4〜8月に焚いた 32 万トンの 2 倍近くむ消費している. 又比較的出水率が 良いといわれた東京電力でも 72 万トン (7.5 億方 $\mathrm{kWh)}$ の年開計画使用量に対し次表のどとく，例年殆んど火力 を焚かない 5 月から相当量の火力発電を計画以上に使用

東京電力に於ける火力発電々力量 (昭26年度計画並に実績) 單位 100 万Wh

\begin{tabular}{c|c|c|c|c|c|c|c|c|c|c|c}
\hline 月 & 5 & 6 & 7 & 8 & 9 & 10 & 11 & 12 & 1 & 2 & 3 \\
\hline 計画 & 8.6 & 11.9 & 38.4 & 61.1 & 65.5 & 66.4 & 92.8 & 108.3 & 98.7 & 86.2 & 101.3 \\
実績 & 28.2 & 52.6 & 30.6 & 67.5 & 73.5 & & & & & & \\
增加比 \\
$(\%)$
\end{tabular}


しでり，引続き火力発電の補給は続いているので石炭 の使用量は逐次增加している。

佾在來火力設備の多くは冬期の渴水用として設計施設 されているので，予備機がなく，この樣に連続的な運轉 を年間を通じて動かすをとは困難であり，適当な時に休 ませて手入れをしないと冬の本格的な渴水時に故障を起 しそれてそ火変なととになるのである。

水力発電は異常渴水のため, 火力発需は最大能力を発 揮している発電量に対して需用の方はどらかというと

(3) 需用の激塻による需給の不均衡

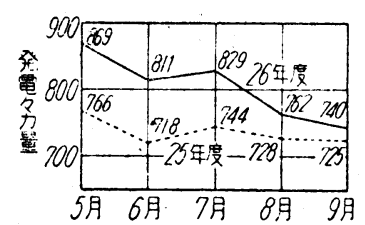

東京電力に招ける発電 需力量增加比較
電力の需用は朝鮮動铜 をキッカケとした座業の 全面的な活潑化並儿例年 ○冬期に於ける電灯需用 の䝬加に上り電力の需用 と供給はアンバランスを 生じている.

では斯かる電力危機をのり切るにはどんな対策がある かといらと, 電源側としては・発蕓所, 眝水池の管强, 火力発電の最大限の補給といらことがあるが，これは差 し迫つた現在の危機を救らには䏕大な建設資金と長年月 を必要とするので閒に合かず, 刃火力発電所も能力以上 は期待出來ない：そこで需用側を調整するごことなる が，止むなく電力制限といら大衆にとつて極めて迷惑な 手段をとらざるを得ないのである。

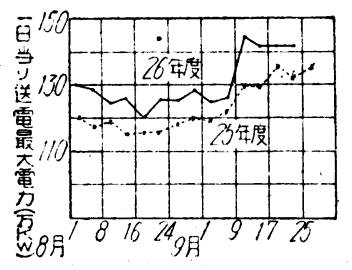

東京電力に扣ける最大電 力の貹加傾向
ての为に 10 月 11 日か ら当分の間公益事業委貝会 の告示により炎の樣な電力 制限措置が用途に應じてと られている。

（1）使用禁止となつた 子ळ

調理用及び湯沸用電熱器

(電氣使用する電熱器総筷量 600 ワット以下のもの)電 氣風吕用電熱器 (公采浴場用を除く), 電氣溫水器, 電氣 製塩, 電氣ボイラー, 広告灯, 看板灯, ‘電飾, ネオンサ イン(公洪標識用のものを除く), 屋外投光器 (交通及び 作業用のものを除く). 多灯式街路灯

（2）時間的に使用を禁止されたもの

$$
\begin{aligned}
& \text { 電灯午前六時牛上り午後五時迄 } \\
& \text { 電熱器 }\left(\begin{array}{c}
600 \text { ワッ } \\
\text { ト以下 }
\end{array}\right) \text { 及び動力 }
\end{aligned}
$$

此の外各電力会社に上つて相違するが, 遏 2 〜 回の 休電日制の実施及び 1 日の電力量を前年同月の60〜80\% て制限されている.
之等の制限は電灯をその期閒だけは切断されるのであ るが, 此の外に使い乍ら電力の使所を節娍する方法があ る.これは照明の方では光源から出た光を能率良く使う ことである.よく電灯会社から"何割節約して下さい゙ こ御願いすることがあるが，これから此の何割節䄪とい らことが，電力制限に少らない効果のあがることである ということを述べょうと思う。

各家庭の電灯を 1 灯位つ汁たところで, 大したことは あるまい，1工場何千キロという工場で節減した方が効 果があると思えるが，今全国の霄灯需用家が效率の良い 笠をつけて $100 \mathrm{~W}$ を $60 \mathrm{~W}$ に, $60 \mathrm{~W}$ を $40 \mathrm{~W}, 40 \mathrm{~W}$ を 30 といら具合に本均 $20 W$ だけ小さな電球にして同一の明 るさを保持するこをが出來たとしたら, 全国の電灯数は 7143 万灯であるから，なんと信浱川発電所級（最大 $16,500 \mathrm{~kW})$ の発電所が 9 箇所作つたこととなる.又1 1 ケ 月の使用量を計画的に上手に使つて，その使用量の 3 割 節約出來たとすれば約 1 億キロワット時, 即 10 万トン の石炭がうき，これは東京電力で使周する年間計画使用 量の $1 / 7$ に相当する.

これに加えて工場の方も有効活用を図れば更に節減電 力量は增加し, 理想的な狀態でわ電力制限も非常にゆる やかにすることも出來るのではなかるらか.

次にこの有效利用与る上の具体的な方法として照明の 方では资の点が考えられる。

(1) 電球には必らず笠をつけて約 2 割程度小さな電 球に交換しても同じ明るさが得られる。

（2）電球球の代り下螢光灯の如き能率の良い光源を 使うことにょり約 $50 \%$ 電力節約が出來る。

（3）灯具を定期的に掃除することにようて, 約 1 割 の電力量が節約出來る。

（4）電灯を手まめに消して，不用時の無駄な使用を 止めることにより，1〜2割の電力量の節減が可能 である。

(5) 歒店等では店內全般を明るくしないで, 店の 奧, 店頭, 店內さいう䐓序で明るさに段階をつけ, コントラストをつけると, 打客吸引に一層效果考 げ得られるだけでなく電力む節減出來る.

（6）店の奥に㤾光空を設備することによつて, 店の 氣分を明るくし，書閒点灯の必要がなくなるので, 電力節減にもなる。

（7）街路灯の畫間点灯を絕隇することによつて, 全 国使用量 115.5 万 $\mathrm{kWh} \odot 2$ 割 23 万 kWh (約 $4000 \mathrm{~kW}$ ) 程废節減が出來る。

(山口昇一郎) 